General colour above dark bistre brown, the ends of the hairs prominently lighter, buffy brown. Below, similar but lighter. Hinder aspect of pubis buffy to base of hairs.

Skull long and low, with a very deep nasal notch. Teeth on the whole like those of $P$. ceylonicus ( $P$. indicus, Dobs.). Inner incisors long, their secondary cusp well developed, postero-external; outer incisors just equalling in length the secondary cusp on the inner ones and with an indistinct, low, postero-internal, basal cusp, and a posterior hollow for the tips of the lower canines, as in P.ceylonicus. Large premolar close to back of canine; the well-developed small premolar visible with difficulty from without. Lower incisors slender, scarcely overlapping. Lower canines with a broad cingulum, making its section circular. Anterior lower premolar three fourths the height of the second.

Dimensions of the type (measured in spirit) :-

Foream $37 \mathrm{~mm}$. (range 36-39).

Head and body 51 ; tail 36 ; head 18 ; ear 13.5 ; third finger 65 ; tibia 12 ; hind foot (c. u.) 9 ; penis 15 , its terminal portion (with the bone) 11 .

Skull : greatest length 14.5 ; upper length in middle line 12 ; basal length in middle line 10.9 ; zygomatic breadth $10 \cdot 6$; interorbital breadth 6.1 ; constriction 4 ; mastoid breadth 8.6 ; length of brain-case $5 \cdot 7$; front of canine to back of $m^{3} 6$; front of lower canine to back of $m_{3} 6 \cdot 1$.

Hab. Tonkin.

Type. Adult male in British Museum. Collected by Mr. H. Fruhstorfer. Six specimens examined.

This species may be readily distinguished from all its allies by the enormous size of the penis and the presence of a bone in that organ. From Dobson's "Vesperugo affinis," only known from a female, it may be separated by its shorter and fewer-jointed tail, stouter feet, shorter tibiæ, and other characters. P. brachypterus, Temm., of which I have not seen a specimen, has shorter outer incisors and the wingmembrane arises from the tarsus; described originally from an old male in spirit, no mention is made of the penis.

\title{
XLVII.-Notes and Descriptions of some new Species and
} Subspecies of Mustelidæ. By G. E. H. Barrett-Hamilton.

In working through the Mustelidæ in the British Museum of Natural History I find several forms which seem to me to be worthy of recognition mainly because they are either distinguishable as local races of well-known species, or, as in the 
case of the Greenland stoat, are sufficiently differentiated to claim a title to full specific rank.

Firstly, as regards the pine-marten, I find a tendency to deeper coloration and a brighter throat-patch in the southern representatives of the species. I propose for these the subspecific name Mustela martes latinorum, and I take as type of the subspecies a male (no. 95. 4. 16. 1) from the Nurri Mountains, Sardinia, presented by Mr. E. N. Buxton.

In this specimen the general colour is between "sealbrown" * or "mummy-brown," darkest on the tail, limbs, and, to a less degree, the central dorsal region. The yellowish-brown underfur, yellower than in British martens, frequently shows through the long outer hairs. The ears are edged and faced with dirty brownish-white hairs. The extensive throat-patch is rich "orange-buff," deepest near its centre. It reaches from the "interramia" $\dagger$, where it sends forward a small central projection, to slightly behind the region of attachment of the fore limbs, near which it is interrupted by one or two detached areas of the brown colour. Its edges are sinuous.

No dimensions taken from the animal whilst in the flesh accompany the specimen; but it was evidently an adult male, having a hind foot and ear measuring 41 and $35 \mathrm{~mm}$. respectively in the dried skin.

The dimensions of the skull are :-Greatest length $90 \mathrm{~mm}$.; basal length 84 ; palatal length 43 ; zygomatic breadth 51 .

I have also examined examples of this form obtained by Messrs. Oldfield Thomas and R. I. Pocock in Majorca and Minorca.

Amongst the polecats, I find in the south a tendency to assume yellow underfur and face-markings, while in Central Europe the face-markings are more extensive, and both they and the underfur are whiter.

As type of the former subspecies, which may be known as Putorius putorius aureolus, I take no. 94. 3. 12. 1 (a female), killed at Ferrol, Spain, on the 23rd of June, 1893, and presented by Dr. V. L. Seoane.

The colour, above and below, is deep seal-brown, especially dark upon the limbs and chest. The ears are edged with dirty yellowish white, and the cheeks, upper lip, interramia, and a band running up from the latter between the eye and * Names of colours in inverted commas are from Mr. R. Ridgrway's
'Nomenclature of Colors,' 1886 .

† I adopt this term from a suggestion of Mr. Oldfield Thomas. 
ear on each side, but not extending to the crown of the head, are of the same colour. 'The underfur is yellowish buff.

The dimensions of the hind foot and ear, taken from the dried skin, are 61.5 and $19 \mathrm{~mm}$. respectively.

The dimensions of the skull are:-Greatest length $66 \mathrm{~mm}$.; basal length 60 ; palatal length 31 ; zygomatic breadth 44 .

The Central-European polecat, on the other hand, has a nearly white underfur, and the long outer hairs are nearly black. The facial markings also are nearly white and the two bands between the eyes and ears are carried upwards until they meet and form a $\mathbf{V}$-shaped mark, with the blunt point of the $\mathbf{V}$ lying on the forehead between the eyes pointing anteriorly.

'This subspecies may be known as $P$. putorius manium. I take as the type no. 2. 8. 4. 24 (a male), procured by Mr. Zollikofer at Teufin, Apfenzell, Switzerland.

The dimensions are:-Head and body $408 \mathrm{~mm}$; tail (without end-hairs) 145 ; hind foot 62 ; ear 25.

It seems probable that a paper by M. Drion, Jun. *, in which he distinguishes a yellow and a black race of polecat, both existing in Belgium, but with different habits, habitat, and character, was based upon the overlapping and intergrading of these or other continental races. M. Drion states that in both of his races he found the male about one third larger and stouter than the female, and the young dark in colour and hardly assignable to either form.

The large weasel named by Pallas Mustela sibirica, and which has a wide range in Siberia, seems to be divisible into a number of subspecies. In this animal there is probably a considerable difference between the summer and winter coats, the former being some shade of brown, the latter of yellow. I find two forms which cannot be identified with any previously published description of any known subspecies. These are:-

\section{Putorius sibiricus noctis, subsp. n.}

Form as in $P$. sibiricus typicus.

Coloration. Above near "vandyke-brown," shading gradually without line of demarcation into a tint between " russet" and "tawny olive" beneath; the tail a shade lighter than the brown of the upper surface, but with the tip darker. Anterior

* Bull. Acad. Roy. Sci. Lett. Beaux-Arts Belg. sér, 3, t. xiv. pp. 365368 ; translated in 'Zoologist,' 1895, pp. 366-369. 
half of interramia, edges of lower lips, angles of mouth, and a sprinkling of hairs about the nose white.

Dimensions : from label, "length 20 inches"; hind foot (measured in dried skin) without claws $54 \mathrm{~mm}$.; tail (ditto) including end-hairs about 170 ; ear about 15 .

The skull is not perfect, but presents the following dimensions :- palatal length $25 \mathrm{~mm}$.; zygomatic breadth 31 . The mesopterygoid fossa is attenuated anteriorly; the incisive foramina are ample and elongated.

Type (an almost mature male), no. 99.3. 1. 11, from San-yen-tze, China, 5th August, 1896; procured by Mr. F. W. Styan.

Putorius sibiricus noctis is clearly separated by its dull coloration from all its allies of the Asiatic mainland. The type is evidently in summer coat.

\section{Putorius sibiricus miles, subsp. $\mathrm{n}$.}

Form as in P. sibiricus typicus.

Coloration. Above between "russet" and "cinnamonrufous," shading into "orange-rufous" or "ochraceous rufous" on the underside, and becoming darker on the upper surface of the head. Upper surfaces of the feet, interramia, upper lips, and a spot behind each nostril dirty white, shading into ochraceous tints on the throat.

Dimensions from the dried skin:-Hind foot $45 \mathrm{~mm}$.; ear 15 .

There is no skull.

Type. No. 74. 1. 16. 2, from Dauria, Eastern Siberia; received from Professor Taczanowski.

The bright underside of this weasel renders it distinguishable at a glance from all other described forms.

Turning to the true weasels, I may remark here that the subspecific name Putorius nivalis italicus proposed by me for the Italian weasel is preoccupied by Achille Costa's name "var. meridionalis" $*$, of which it must accordingly stand as a synonym. The type locality of $P$. nivalis meridionalis is " in Italia meridionali continentali."

Amongst the ermines or stoats I find the following forms. Firstly, a specimen from British North America does not agree with any description by American naturalists of the

* Ann. del Museo Zool. della R. Univ. di Napoli, anno 1865, p. 40 (dated 1869). 
various forms which inhabit that continent. It may be known as

\section{Putorius arcticus imperii, subsp. $\mathrm{n}$.}

Form as in P. ermineus or arcticus, but smaller and with the tail longer than that of the latter.

Coloration of type specimen. Upperside (with exceptions to follow) golden brown (between "tawny olive," "raw umber," and "mars brown "), the crown of the head darker. Dorsal borders of ears, a tuft of hairs at their anterior angle on each side, upper lips, chin, interramia, and upper throat white. Underside (except as above) deep "primrose-yellow," including the inner and posterior surfaces of the fore legs, the whole of the fore feet, the distal half and inner side of the hind feet, and the under surface of the tail nearly to the dark pencil. Line of demarcation well defined and straight, the brown colour not encroaching on the underside. Tail with conspicuous dark terminal pencil.

The skull corresponds with Dr. Hart Merriam's description of that of $P$. arcticus.

Dimensions of the type (taken from the dried skin) :Hind foot $38 \mathrm{~mm}$; ear 20 ; tail (including terminal hairs) 129 ; tail-pencil 71 .

The somewhat damaged skull has:-Zygomatic breadth $25 \mathrm{~mm}$.; palatal length 17 ; length of upper molar series 11 , of lower molar series 12 .

Type. No. 63. 10. 28. 1, from Fort Simpson, British Columbia; received from Mr. B. R. Ross.

$P$. arcticus imperii appears to be a smaller race of $P$. arcticus, from which it differs also in the possession of white ear-borders and upper lips, a less deeply yellow underside, and a longer tail.

Secondly, the specimens long since brought home by Mr. H. C. Hart from Greenland show that there are in that country two forms of stoat. Of these the first is a welldefined species, apparently not very clearly related to its allies either of the Old World or of the New. It may be known as

\section{Putorius audax, sp. n.}

General characters.-Size moderate ; tail short, with welldeveloped dark pencil; colours of upperside not encroaching upon underside.

Coloration. Above between "wood-brown" and "mars 
brown," the line of demarcation straight and decided. Below white, tinged with yellow on the flanks, neck, and near the legs, the white colour including also the upper lips, fore and hind feet (but not conspicuously), the inner and anterior surfaces of the limbs, but not the under surface of the tail, which is barely lighter than the upper surface. Tail with dark pencil commencing at about the middle point. Underfur of upper surface near white.

The skull, as compared with that of American stoats, is characterized by its broad, somewhat massive, and depressed rostrum and moderately conspicuous postorbital processes. It is shorter and far less massive than that of $P$. ermineus; the posterior region has a peculiar rounded appearance when viewed from above, which is characteristic, but difficult to describe. The audital bullæ are shortened as compared with those of $P$. ermineus.

Dimensions of the type (taken from the dried skin):Hind foot (without claws) $40 \mathrm{~mm}$; tail (including terminal hairs) 196 ; tail-pencil 63.

The somewhat damaged skull has a zygomatic breadth of about $25 \mathrm{~mm}$.; palatal length 18 ; length of upper molar series 10.50 , of lower molar series 12 .

Type. No. 78. 6. 26. 5 ; secured by Mr. H. C. Hart at Discovery Bay, North Greenland.

A second skin was brought home by $\mathrm{Mr}$. Hart from latitude $82^{\circ} \mathrm{N}$., longitude $59^{\circ} 20^{\prime} \mathrm{W}$., in Hall Land, in the very far north of Greenland. This specimen appears to me to be a form of P. arcticus, Merriam, and I accordingly propose for it the subspecific name

\section{Putorius arcticus polaris, subsp. $\mathrm{n}$.}

Form and general characters as in P. arcticus, Merriam.

Coloration. Above golden brown, the underfur near white; upper lips, interramia, and upper throat white; remainder of underside deep "primrose-yellow," this colour running in a slightly lighter shade to the underside of the tail (except the terminal pencil) and the fore feet. Line of demarcation direct and as in P. audax.

'There were no dimensions or skull with this specimen. In the dried skin the hind foot measures about $38 \mathrm{~mm}$. and the tail (including terminal hairs) 105, with a pencil of 62 .

Type. No. 78. 6. 19. 11; locality as above. Ann. \& Mag. N. Hist. Ser. 7. Vol. xiii. 
Lastly, I find that true P. ermineus of Scandinavia * may be distinguished from its southern representatives, such as those of Britain, by the fact that it has the underside of the tail (except the distal part occupied by the terminal pencil) of the same colour as the underside generally, whereas in British stoats the tail (except in cases of winter whitening) is unicoloured all round. A second, and, to my mind (since it is of deep physiological significance), far more important distinction is the absence of winter whitening in southern stoats. Southern examples may therefore be distinguished subspecifically under the name of

Putorius ermineus stabilis, subsp. n.,

with no. 98. 5. 13. 2 (a female, dated the 18th of February, 1895), from Blandford, Dorset, presented by Mr. J. C. ManselPleydell, as the type.

I add a description of the British stoat, not taken from the type, but from a series:-

Coloration. Entire upper surface of both sexes (except the end of the tail) in summer with the long outer hairs between "mummy brown" and "mars brown," the underfur lighter and near " isabella colour," usually concealed, but in specimens in old faded cuat showing through the thin outer hairs. Under surface (except that of the tail) white, with a strong wash of yellow which about reaches "primrose-yellow" in extreme, but by no means rare, cases at all seasons, the white colour extending to the upper lips and the inner surfaces of all four legs to the ankles and wrists, but not to the tail. Line of demarcation definite and decided, the brown colour not encroaching upon the underside. Tail with the hairs

* The nomenclature of the northern stoats must be regarded as entirely provisional. Dr. Merriam clearly emphasizes the close relationship between his arcticus and true ermineus by the remark that the former, " though specifically distinct, is strictly the American representative of the Old-World erminea " ('North-American Fauna,' no. 11, p. 16, 1896). Remembering, then, what different conceptions are prevalent between naturalists of the Old and New World in regard to the uses of specific and subspecific names, that Baird's Putorius Kuneii ('Mammals of North America \&c.', pp. 172-3, 1859) of Chulkchi-Land and Bering's Straits (Arikamtchitchi Island) is a small yet "perfect miniature " of ermineus, and that Dr. Allen cannot find any tangible characters whereby to separate stoats from North-eastern Siberia and Europe (Bull. Amer. Mus. N. Hist. vol. xix. art. iv. pp. 174-176, March 31, 1903), we may look forward to the strong possibility that both Kaneii and arcticus with all its subforms may eventually find their true status as subspecies of erminens. 


\section{$2 \mathrm{BHL}$ Biodiversity Heritage Library}

Barrett-Hamilton, Gerald Edwin Hamilton. 1904. "XLVII.-Notes and descriptions of some new species and subspecies of Mustelidæ." The Annals and magazine of natural history; zoology, botany, and geology 13, 388-394. https://doi.org/10.1080/00222930408562463.

View This Item Online: $\underline{\text { https://www.biodiversitylibrary.org/item/54611 }}$

DOI: https://doi.org/10.1080/00222930408562463

Permalink: https://www.biodiversitylibrary.org/partpdf/53931

\section{Holding Institution}

Smithsonian Libraries

\section{Sponsored by}

Smithsonian

\section{Copyright \& Reuse}

Copyright Status: Public domain. The BHL considers that this work is no longer under copyright protection.

This document was created from content at the Biodiversity Heritage Library, the world's largest open access digital library for biodiversity literature and archives. Visit BHL at https://www.biodiversitylibrary.org. 